\title{
CHANGE IN CROPPING PATTERN UTILIZING NARMADA MAIN CANAL WATER: A CASE STUDY OF BARMER DISTRICT
}

\author{
Payal Zaveri ${ }^{1}$ Ankita Parmar ${ }^{2}$ \\ ${ }^{1},{ }^{2}$ Lecturer, Civil Engineering Department, Sarvajanik College of Engineering Technology, Gujarat, India, \\ zpayal81@gmail.com,ankita_s611@yahoo.co.in
}

\begin{abstract}
Irrigation is the most important determinant which triggered chain reaction in Indian agriculture. The scenario of canal irrigation system has change due to performance and environmental problems, which lead to exploiting of alternate sources. Considering the importance of Narmada main canal water and its effect on cropping pattern, the study is taken up in Barmer district of Rajasthan. This zone of Rajasthan has high saline water and hence agriculture output was very poor. More than $65 \%$ of lands were barren and could grow only throny trees. Bajara is the dominant crop in this district. In Barmer before Narmada main canal water most of the areas were irrigated by wells only and total irrigated area was 106249 ha. After Narmada main canal water supply 879 ha. area is irrigated by canal water and total irrigated area is increased to 130193 ha. After Narmada main canal water area of wheat is decreased by $0.1 \%$, production is increased by $24.76 \%$ and yield is increased by $24.9 \%$. Area of jowar is increased by $12.66 \%$, production is increased by $21.79 \%$ and yield is also increased by $13.58 \%$. Area of onion is decreased by $20.25 \%$, production is also decreased by $47.45 \%$ and yield is going down upto $30.11 \%$.
\end{abstract}

Index Terms: Barmer Canal Irrigation, Narmada Main Canal Water, Increasing Crop production

\section{INTRODUCTION}

Indian agriculture is a prelude to economic development and a pre-requisite for poverty alleviation and overall economic development. Agriculture is the principal occupation of the people of India. More than 70 per cent of the working population derives their livelihood by cultivation. Moreover, in India agriculture is the basis of the economic structure of India, for it is not only the source of raw materials for the principal industries of India such as jute textiles, sugar and cotton but it also accounts for the maximum portion of the total income. Food grain crops are dominant everywhere and they cover as much as three fourth of the total cropped area in India. Sources of irrigation in India are tanks, wells (including tube wells), canals, etc. Net irrigated area: $60.85 \%$ is irrigated by wells (including tube wells and pumping sets), $29.24 \%$ by canals, $4.62 \%$ by tanks \& $5.29 \%$ by other sources. Cropping pattern is defined as the spatial representation of crop rotations, or as the list of crops that are being produced in an area and their sequence in time.

Barmer districts of Rajasthan have high saline water, very poor monsoon and agriculture activity was very poor. The Narmada main canal was inaugurated on 24 April 2008; the Narmada main canal comes as a blessing for the farmers and residents of Barmer district. After Narmada main canal water for the people of Barmer district of Rajasthan, it will not only mean end of water scarcity, but will also help 233 villages in the area to irrigate 2,50,000 hectares of land. Apart from this,
589 areas in Barmer - a total of 1,107 villages with a population of 4.5 million will be able to use the water for drinking purposes. Venkataramanan and Prahladachar 12 (1980) has studied the growth rates and cropping pattern changes in agriculture in six states from 1950 to 1975. Mishra P.4 (1990) analyzed water management in the arid agriculture of Barmer district. Sharma J. L.7 (1990) has studied inter-state disparities in growth of agriculture in India from 1966-67 to 1987-88. Increased production was statistically nonsignificant in Gujarat, Tamil Nadu and Rajasthan states. Shivakumar P.9 (1994) reported that in Karnataka, there was statewide shift from food based agriculture to horticulture, sericulture, dry land crops and forestry. Vivekananda and Sathyapriya12 (1994) has studied the Karnataka's changing cropping pattern and reported that the share of area under all cereal crops declined from $55 \%$ to $47 \%$ between 1956-57 and 1989-90 Parmer et al. 5 (1995) examined the degree of change in cropping pattern in the four districts of south Gujarat during the period 1960-61 to 1989-90. Singh et al. 10 (1997) studied the cropping pattern during pre (1959-60 to 1968-69) and post (1969-70 to 1990-91) green revolution period in the three agro-climatic zones of the plateau region of Bihar. Carlyle W. J. 2 (2002) has studied changes in cropping patterns from the early 1960 to the mid 1990 in the Canadian Prairies using census data. Sharma P. K. and Sood Anil 8 (2003) have studied spectacular progress in agriculture in Punjab during the last three decades with the help of Remote Sensing and GIS. Kushwaha, S. S. and Gajja, B. L.3 (2009) has studied the change in the cropping pattern in Rajasthan, India. The crop 
diversification had been witnessed in favoure of oilseed crops. Punithavathi J. and Baskaran R. 6 (2010) has studied 20 crops with varying hectares in Papanasam taluka, Tamildu and determined dominant crops out of this 20 crops. Bhatt M. M and Shah A.R.1 (2011) has studied that the new agricultural technology and conserving of state farms into sharkets and dekhans has bought changes in the traditional cropping pattern in Uzbekistan, particularly in the main food crops-wheat and rice.

\section{STUDY AREA}

Rajasthan the largest state of India with high population growth and has agrarian economy with greater drought vulnerability. The rural communities in Rajasthan are mainly dependent on rain-fed agriculture. Rajasthan has cultivated area of almost 20 million hectares but due to some unavoidable circumstances on $20 \%$ of the total cultivated area is irrigated. Study area includes Barmer district of Rajasthan. Barmer is located between $24^{\circ} 58^{\prime}$ and $26^{\circ} 32^{\prime}$ North latitude and between $70^{\circ} 5^{\prime}$ and $72^{\circ} 52^{\prime}$ East longitude 2. These zones of Rajasthan have high saline water (khaara paani) hence the agricultural output was very poor. More than $65 \%$ of lands were barren and could grow only thorny trees. Avg. rainfall is $277 \mathrm{~mm}$ in Barmer. Groundwater is only source of irrigation in these zones. The Narmada main canal was inaugurated on 24 April 2008; the Narmada main canal comes as a blessing for the farmers and residents of Barmer district. After Narmada main canal water for the people of two district of Rajasthan, it will not only mean end of water scarcity, but will also help 233 villages in the area to irrigate 2,50,000 hectares of land.

\section{METHODOLOGY}

Selection of study area is done in such a way that the region which gets maximum benefits of Narmada main canal water. Data for source wise irrigated area before \& after Narmada main canal are collected and analyzed. Percentage of net irrigated area before \& after Narmada main canal is determined for Barmer district. Area, production \& yield of various crops before \& after Narmada main canal for both regions are collected from Individual change in percentage of area, production \& yield of various crops before \& after Narmada main canal are determined. Percentage increase \& decrease in area, production \& yield of various crops before \& after Narmada main canal are determined and concern charts are drawn.

\section{DATA ANALYSIS}

Source wise net irrigated areas for Barmer before \& after Narmada Canal are tabulated in table 1 and concern charts is shown in figure 1 .
Area, production \& yield of various crops from 2001-2011 are collected both for Barmer 3. These data are separated with respect to before \& after Narmada main canal water supply. [(2001-2007), (2008-2011)] Table $2 \& 3$ show these data in terms of min. \& max range for Barmer. Individual changes in percentages of area, production \& yield of various crops for Barmer before and after Narmada Canal is tabulated in table 4 and table 5 respectively. Table 6 shows percentage increase or decrease in area, production \&yield of various crops for Barmer before \& after Narmada main canal. Percentage increase \& decrease in area, production \& yiled of various crops before \& after Narmada main canal for Barmer area are shown in figure 4 , figure $5 \&$ figure 6 respectively.

\section{Source Wise Irrigated Area:}

Table: 1 Net irrigated areas (in ha.) for Barmer before \& after Narmada canal

\begin{tabular}{|c|c|c|c|c|c|c|}
\hline Year & $\begin{array}{l}\mathrm{Ca} \\
\text { na } \\
1\end{array}$ & $\begin{array}{l}\text { Tan } \\
\mathrm{k}\end{array}$ & $\begin{array}{l}\text { Tube } \\
\text { well }\end{array}$ & $\begin{array}{l}\text { Other } \\
\text { well }\end{array}$ & $\begin{array}{l}\text { Other } \\
\text { source }\end{array}$ & Total \\
\hline $\begin{array}{l}2001- \\
2002 \\
\end{array}$ & 0 & 0 & 7003 & 89052 & 151 & 96206 \\
\hline $\begin{array}{l}2002- \\
2003\end{array}$ & 0 & 0 & 11264 & 110340 & 20 & 121624 \\
\hline $\begin{array}{l}2003- \\
2004\end{array}$ & 0 & 0 & 15223 & 83650 & 0 & 98873 \\
\hline $\begin{array}{l}2004- \\
2005\end{array}$ & 0 & 0 & 14401 & 93298 & 0 & 107699 \\
\hline $\begin{array}{l}2005- \\
2006\end{array}$ & 0 & 0 & 16360 & 92532 & 20 & 108912 \\
\hline $\begin{array}{l}2006- \\
2007\end{array}$ & 0 & 8 & 25856 & 77687 & 634 & 104185 \\
\hline $\begin{array}{l}2007- \\
2008\end{array}$ & 0 & 0 & 29548 & 96621 & 1437 & 127606 \\
\hline $\begin{array}{l}2008- \\
2009 \\
\end{array}$ & $\begin{array}{l}11 \\
7 \\
\end{array}$ & 0 & 38358 & 91521 & 390 & 130386 \\
\hline $\begin{array}{l}2009- \\
2010\end{array}$ & $\begin{array}{l}87 \\
9\end{array}$ & 0 & 40765 & 89754 & 1189 & 132587 \\
\hline
\end{tabular}

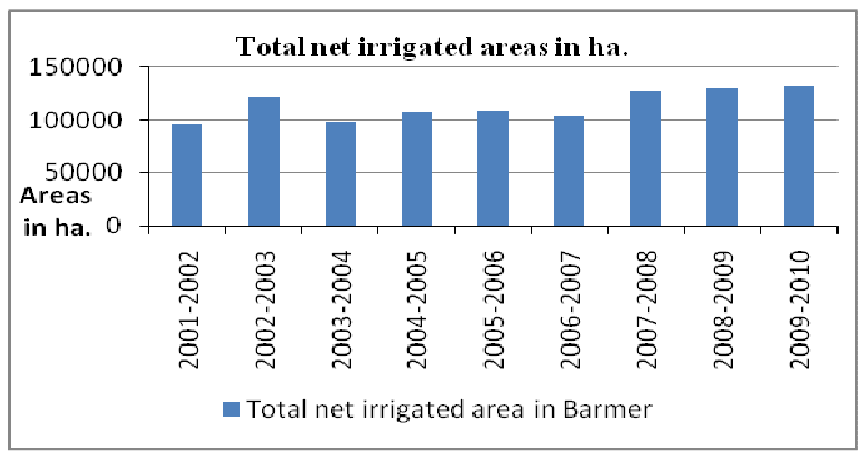

Fig: 1 Year wise total net irrigated area of Barmer before \& after canal 
Table: 2 Area, production \& yield of various crops for Barmer before Narmada canal

\begin{tabular}{|l|l|l|l|l|}
\hline Sr no & Name of crop & $\begin{array}{l}\text { Area in ha. } \\
(2001-2007)\end{array}$ & $\begin{array}{l}\text { Production } \\
\text { in tonnes } \\
(2001-2007)\end{array}$ & $\begin{array}{l}\text { Yield in } \\
\text { tonnes/ha } \\
(2001-2007)\end{array}$ \\
\hline 1 & Wheat & $12158-18400$ & $10900-42911$ & $0.9-2.79$ \\
\hline 2 & Jowar & $360-3788$ & $46-1744$ & $0.13-0.71$ \\
\hline 3 & Bajara & $777384-1020181$ & $5805-563591$ & $0.01-0.55$ \\
\hline 4 & Maize & $9-111$ & $8-161$ & $0.89-1.83$ \\
\hline 5 & Barley & $15-147$ & $39-342$ & $1.81-2.6$ \\
\hline 6 & Gram & $2-3152$ & $2-2721$ & $0.47-1$ \\
\hline 7 & Moong & $33217-56377$ & $1127-34584$ & $0.02-0.63$ \\
\hline 8 & Moth & $33217-262866$ & $0.1-217192$ & $0-0.88$ \\
\hline 9 & Groundnut & $7-235$ & $11-320$ & $0.67-1.57$ \\
\hline 10 & Sesamum & $1634-4562$ & $0.1-2359$ & $0-0.57$ \\
\hline 11 & Rapeseed \& Mustard & $2490-40176$ & $2257-37920$ & $0.76-1.31$ \\
\hline 12 & Castor Seed & $4196-18494$ & $3771-14818$ & $0.48-1.24$ \\
\hline 13 & Dry Chillies & $21-70$ & $10-65$ & $0.15-0.95$ \\
\hline 14 & Onion & $1-152$ & $2-231$ & $0.91-2$ \\
\hline & & & & \\
\hline
\end{tabular}

Table: 3 Area, production \& yield of various crops for Barmer after Narmada canal

\begin{tabular}{|l|l|l|l|l|}
\hline $\begin{array}{l}\text { Sr } \\
\text { no }\end{array}$ & Name of crop & Area in ha. (2008-2011) & $\begin{array}{l}\text { Production } \\
\text { in tones } \\
(2008-2011)\end{array}$ & $\begin{array}{l}\text { Yield in } \\
\text { tonnes/ha } \\
(2001-2007)\end{array}$ \\
\hline 1 & Wheat & $11467-15200$ & $9986-23127$ & $0.9-2.79$ \\
\hline 2 & Jowar & $1221-2074$ & $117-1800$ & $0.13-0.71$ \\
\hline 3 & Bajara & $960403-1011401$ & $18402-166442$ & $0.01-0.55$ \\
\hline 4 & Maize & $1-15$ & $1-28$ & $0.89-1.83$ \\
\hline 5 & Barley & $56-72$ & $156-186$ & $1.81-2.6$ \\
\hline 6 & Gram & $35-113$ & $18-53$ & $0.47-1$ \\
\hline 7 & Moong & $45965-57944$ & $364-6211$ & $0.02-0.63$ \\
\hline 8 & Moth & $184567-231623$ & $3649-40608$ & $0-0.88$ \\
\hline 9 & Groundnut & $305-688$ & $526-1147$ & $0.67-1.57$ \\
\hline 10 & Sesamum & $2139-7550$ & $38-1361$ & $0-0.57$ \\
\hline 11 & Rapeseed \& Mustard & $10249-24715$ & $6674-15842$ & $0.76-1.31$ \\
\hline 12 & Castor Seed & $21303-39440$ & $11386-30771$ & $0.48-1.24$ \\
\hline 13 & Dry Chillies & $28-32$ & $14-21$ & $0.15-0.95$ \\
\hline 14 & Onion & $16-101$ & $3-80$ & $0.91-2$ \\
\hline
\end{tabular}


Table: 4 Individual percentages of area, production \& yield of various crops for Barmer before Narmada Canal

\begin{tabular}{|l|l|l|l|l|}
\hline $\begin{array}{l}\text { Sr } \\
\text { no }\end{array}$ & $\begin{array}{l}\text { Name } \\
\text { of crop }\end{array}$ & $\begin{array}{l}\text { Individual } \\
(\%) \text { area } \\
\text { before }\end{array}$ & $\begin{array}{l}\text { Individual } \\
(\%) \\
\text { production } \\
\text { before }\end{array}$ & $\begin{array}{l}\text { Individual } \\
(\%) \text { yield } \\
\text { before }\end{array}$ \\
\hline 1 & Wheat & 0.93 & 16.45 & 13.85 \\
\hline 2 & Jowar & 0.11 & 0.40 & 2.51 \\
\hline 3 & Bajara & 59.17 & 11.63 & 0.15 \\
\hline 4 & Maize & 0.00 & 0.02 & 9.11 \\
\hline 5 & Barley & 0.00 & 0.08 & 16.43 \\
\hline 6 & Gram & 0.01 & 0.09 & 4.95 \\
\hline 7 & Moong & 3.12 & 4.96 & 1.22 \\
\hline 8 & Moth & 14.03 & 37.47 & 2.08 \\
\hline 9 & Groundnut & 0.00 & 0.11 & 14.35 \\
\hline 10 & Sesamum & 0.21 & 0.44 & 1.57 \\
\hline 11 & $\begin{array}{l}\text { Rapeseed \& } \\
\text { Mustard }\end{array}$ & 0.91 & 8.89 & 7.60 \\
\hline 12 & Castor Seed & 0.72 & 5.87 & 6.31 \\
\hline 13 & Cotton (Lint) & 0.00 & 0.00 & 6.96 \\
\hline 14 & Dry Chillies & 0.00 & 0.01 & 3.66 \\
\hline 15 & Onion & 0.00 & 0.06 & 8.68 \\
\hline 16 & Guar Seed & 20.73 & 13.42 & 0.50 \\
\hline
\end{tabular}

Table: 5 Individual percentages of area, production \& yield of various crops for Barmer after Narmada Canal

\begin{tabular}{|l|l|l|l|l|}
\hline $\begin{array}{l}\text { Sr } \\
\text { no }\end{array}$ & Name of crop & $\begin{array}{l}\text { Individual } \\
(\%) \quad \text { area } \\
\text { after }\end{array}$ & $\begin{array}{l}\text { Individual } \\
(\%) \\
\text { production } \\
\text { after }\end{array}$ & $\begin{array}{l}\text { Individual } \\
(\%) \text { yield } \\
\text { after }\end{array}$ \\
\hline 1 & Wheat & 0.90 & 14.89 & 21.77 \\
\hline 2 & Jowar & 0.14 & 0.34 & 3.12 \\
\hline 3 & Bajara & 55.46 & 24.40 & 0.54 \\
\hline 4 & Maize & 0.00 & 0.00 & 9.36 \\
\hline 5 & Barley & 0.00 & 0.05 & 18.79 \\
\hline 6 & Gram & 0.01 & 0.04 & 5.08 \\
\hline 7 & Moong & 3.37 & 4.49 & 1.76 \\
\hline 8 & Moth & 13.70 & 18.70 & 1.76 \\
\hline 9 & Groundnut & 0.04 & 0.30 & 9.90 \\
\hline 10 & Sesamum & 0.29 & 0.69 & 3.05 \\
\hline
\end{tabular}




\begin{tabular}{|l|l|l|l|l|}
11 & $\begin{array}{l}\text { Rapeseed \& } \\
\text { Mustard }\end{array}$ & 1.15 & 4.17 & 4.74 \\
\hline 12 & Castor Seed & 1.62 & 7.90 & 6.44 \\
\hline 13 & Cotton (Lint) & 0.00 & 0.00 & 3.79 \\
\hline 14 & Dry Chillies & 0.00 & 0.00 & 4.07 \\
\hline 15 & Onion & 0.00 & 0.01 & 4.40 \\
\hline 16 & Guar Seed & 23.25 & 23.94 & 1.35 \\
\hline
\end{tabular}

Table: 6 Percentage increase or decrease in area, production and yield for Barmer

\begin{tabular}{|c|c|c|c|c|}
\hline $\begin{array}{l}\mathrm{Sr} \\
\text { No }\end{array}$ & Name of Crop & Area & $\begin{array}{l}\text { Producti } \\
\text { on }\end{array}$ & Yield \\
\hline 1 & Wheat & -0.10 & 24.76 & 24.90 \\
\hline 2 & Jowar & 12.66 & 21.79 & 13.58 \\
\hline 3 & Bajara & -1.91 & 58.70 & 58.42 \\
\hline 4 & Maize & -61.90 & -59.63 & 4.15 \\
\hline 5 & Barley & -7.69 & 9.88 & 9.49 \\
\hline 6 & Gram & -8.68 & -4.46 & 4.17 \\
\hline 7 & Moong & 5.28 & 24.81 & 20.93 \\
\hline 8 & Moth & 0.15 & -4.44 & -5.45 \\
\hline 9 & Groundnut & 74.39 & 66.52 & -15.61 \\
\hline 10 & Sesamum & 16.76 & 48.61 & 34.33 \\
\hline 11 & $\begin{array}{ll}\text { Rapeseed } \quad \& \\
\text { Mustard }\end{array}$ & 12.65 & -7.53 & -20.45 \\
\hline 12 & Castor Seed & 39.54 & 42.25 & 3.83 \\
\hline 13 & Cotton (Lint) & -15.79 & -40.98 & -26.80 \\
\hline 14 & Dry Chillies & -22.08 & -14.29 & 8.11 \\
\hline 15 & Sweet Potato & - & - & - \\
\hline 16 & Onion & -20.25 & -47.44 & -30.11 \\
\hline 17 & Guar Seed & 7.06 & 53.14 & 48.15 \\
\hline 18 & Small Millets & - & - & - \\
\hline 19 & Arhr & - & - & - \\
\hline 20 & Urad & - & - & - \\
\hline 21 & Lineseed & - & - & - \\
\hline 22 & Tobacco & - & - & - \\
\hline 23 & Potato & - & - & - \\
\hline
\end{tabular}




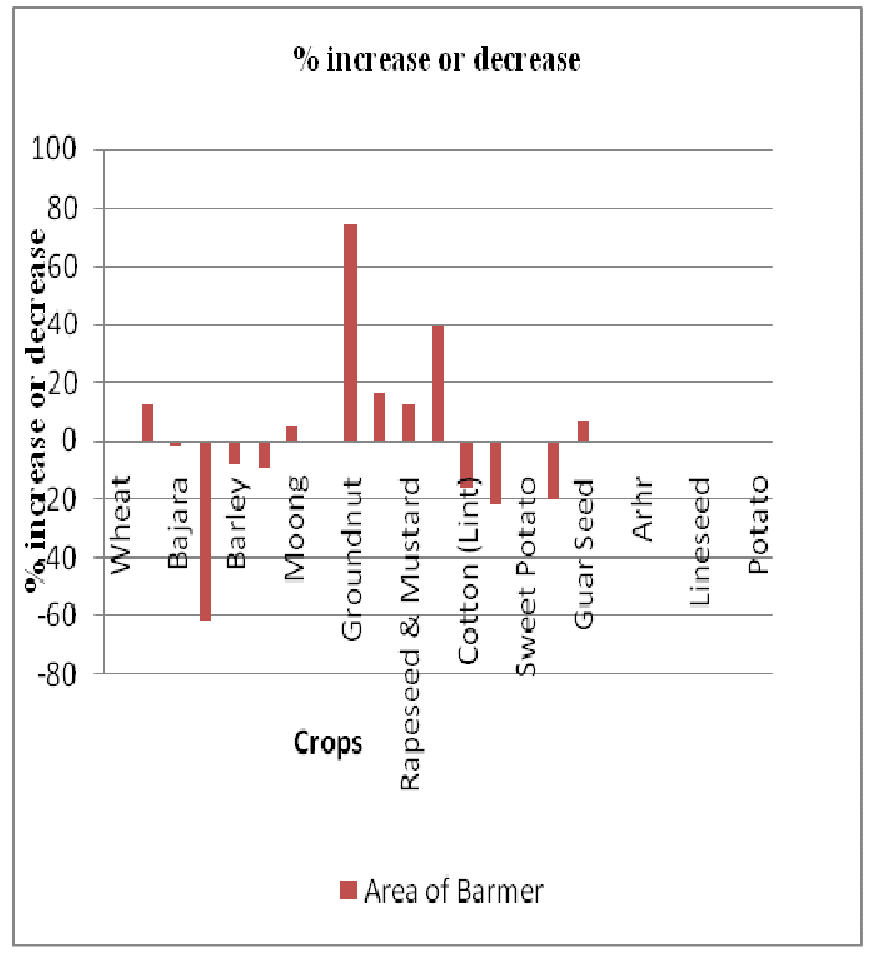

Fig: 4 Percentage increase or decrease in area of Barmer

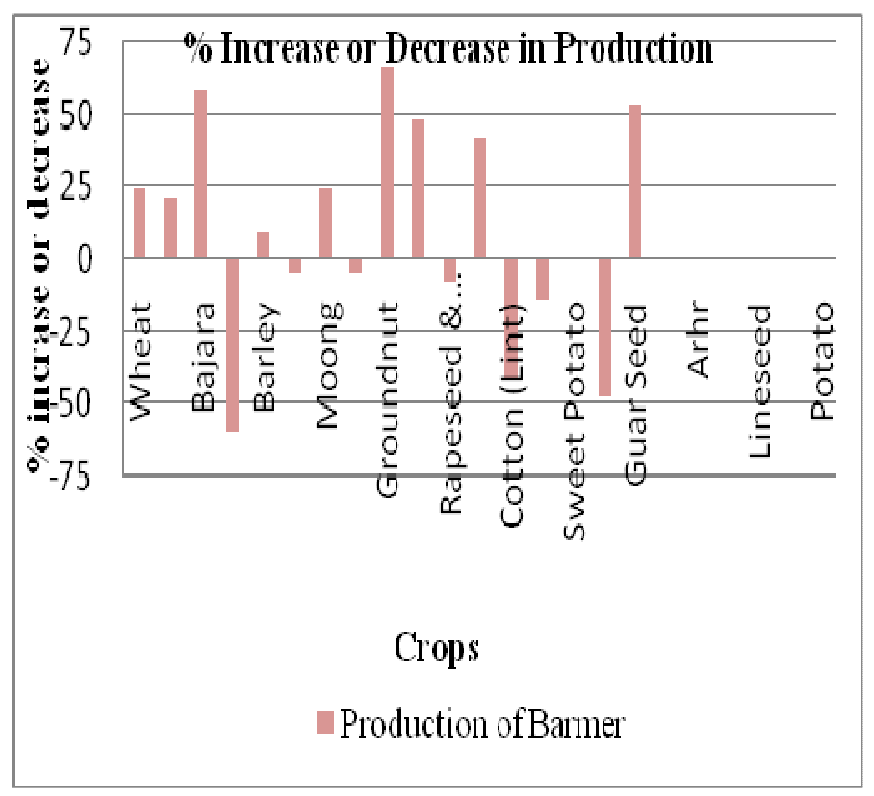

Fig: 5 Percentage increase or decrease in production of Barmer

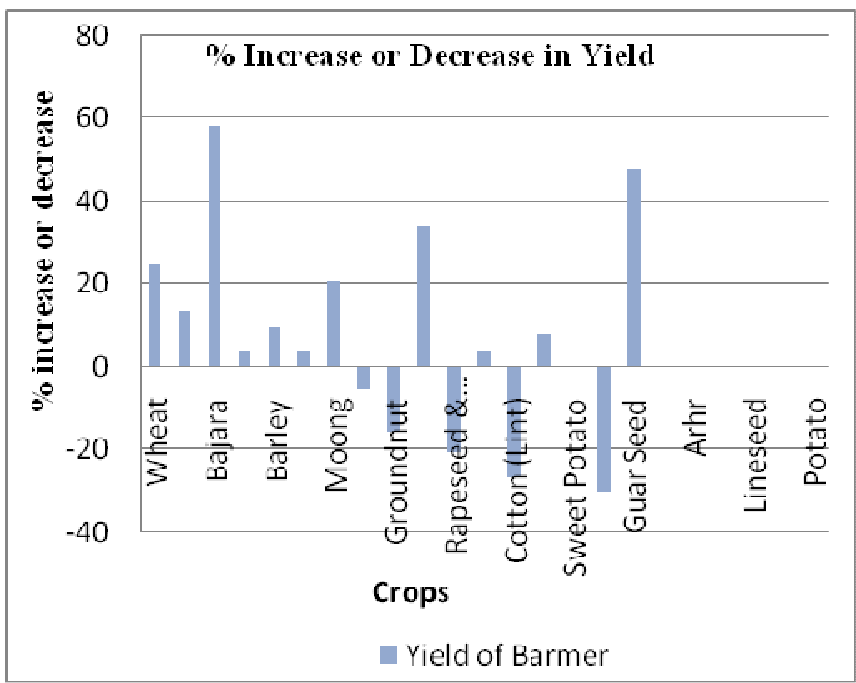

Fig: 6 Percentage increase or decrease in yield of Barmer

\section{FINDINGS}

1. Area of Groundnut is increased by $74.39 \%$ and production is increased by $66.52 \%$.

2. Area, production and yield of Moong is also increased by $5.28 \%, 24.81 \%$ and $20.93 \%$ respectively.

3. Area and production of Maize is decreased by $61.90 \%$ and $59.63 \%$.

4. Area, production and yield of onion are decreased tremendously.

5. Area, production and yield of Sesamum are increased by $16.76 \%, 48.61 \%$ and $34.33 \%$ respectively.

6. Area, production and yield of Guar Seed are also increased by $7.06 \%, 53.14 \%$ and $48.15 \%$ respectively.

\section{CONCLUSIONS}

From the analysis of above study it can be concludes that Narmada main canal water is blessing for farmers of Barmer district of Rajasthan. More than $65 \%$ of lands were barren and could grow only thorny trees. Before Narmada main canal water availability, bajra was the major crops for Barmer region. In Barmer before Narmada main canal water availability most of the areas were irrigated by wells and total irrigated area was 106249 ha. After availability of Narmada main canal water total irrigated area is increased $18 \%$. After Narmada main canal water area of wheat is decreased, production is increased and yield is also increased. Area of Jowar is increased, production is increased and yield is also increased. Area of onion is decreased, production and yield is going down. Are, production \& yield of most of crops are increased after Narmada main canal water supply. 


\section{REFERENCES}

[1]. Bhatt M. M. and Shah A. R., (2011). "Recent change in cropping patterns and its impact on output of food grains and non-food grains in Uzbekistan." Research Journal of Agricultural Sciences, 2(2), pg: 384-387.

[2]. Carlyle William J., (2002). "Cropping patterns in the Canadian Prairies: Thirty years of change." The Geographical Journal, 168(2), pg: 97-115.

[3]. Kushwa S.S and Gajja B.L., (2009). "Temporal change of cropping pattern in Rajasthan." Journal of Current Agriculture, 33(1/2), pg: 55-62.

[4]. Mishra P., (1990). "Water management in the arid agriculture: A case study of district Barmer." Journal Annals of the National Association of Geographers, India, 10(1), pg: 29-44.

[5]. Parmer G. D., Khunl K. A., Naik G. D. and Desai D. B., (1995). "Acreage dynamics in relation to price and non price parameters - A study of south Gujarat." Agric. Situ. India, 52(8), pg: $545-548$.

[6]. Punithavathi J. and R. Baskaran (2010). "Changes in the cropping pattern, crop concentration, agricultural efficiency In Papanasam Taluka, Thanjavur District, Tamil Nadu." India Recent Research in Science and Technology, 2(5), pg: 01-07.

[7]. Sharma J. L. (1990). "Interstate disparities in growth of agriculture in India. Agric. Situ. India, 45(7), pg : $453-456$.

[8]. Sharma P. K. and Sood Anil (2003). "Remote Sensing and GIS techniques in agriculture development - A case study of Punjab.” Jour. Agric. Physics, 3(1), pg: 174181.

[9]. Shivakumar P. (1994). "Shift in cropping pattern in Karnataka. Bihar.” J. Agric. Mktg., 20(4), pg: 19-22.

[10]. Singh I. J., Rai K. N. and Karwara J. C., (1997). "Regional variation in agricultural performance in India.” Indian J. Agric. Econ., 52(3), pg: 374 - 386.

[11]. Virenderkumar, Sharma S. K and Sharma H. R., (2002). "Changing c ropping pattern in Himachal Pradesh, A district - wise study." Himachal J. Agric. Res., 28(1\&2), pg: 58- 62.

[12]. Vivekananda M. and Sathyapriya V. S., (1994). "Karnataka changing cropping pattern." Agric. Situ. India, 49(6), pg: $441-444$.

\section{WEBOLOGY}

[1]. http://www.mapsofindia.com/maps/rajasthan/districts/b armer.htm

[2]. http://cgwb.gov.in/District_Profile/Rajasthan/Barmer.p df

[3]. http://www.districtsofindia.com/rajasthan/barmer/agric ulture/index.aspx

[4]. http://www.sardarsarovardam.org/

[5]. http://waterresources.rajasthan.gov.in/4narmada.htm

[6]. http://www.nri.gujarat.gov.in/narmada-canal.html 